\title{
Penerapan Kegiatan Bimbingan Berkelanjutan Dalam Meningkatkan Kemampuan Guru Mata Pelajaran dalam Menyusun Perangkat Pembelajaran di SD Negeri 10 Setia Bakti Tahun Pelajaran 2019/2020
}

\author{
Saloma, S.Pd.SD \\ SD Negeri 10 Setia Bakti
}

\begin{abstract}
Abstrak
Perangkat Pembelajaran Seperti Silabus, RPP, Media Pembelajaran, Bahan Ajar, dan lai sebagainya merupakan salah satu pokok administras guru dari beberapa komponen lainnya dalam proses pembelajaran. Kelemahan dalam menyusun perangkat tersebut sering terjadi pada saat sebelum proses pelaksanaan pembelajaran, dengan demikian dalam menyusun dan merancang perangkat tersebut diharapkan benar-benar efesien dan bermakna. Setelah melakukan supervisi perlu dilakukan perubahan oleh setiap guru dalam menyusun perangkat pembelajaran yang sesuai dengan materi yang diajarkan. PTS ini dilakukan dalam 2 (dua) siklus. Penelitian ini dilaksanakan pada bulan November s.d Desember 2019 di SD Negeri 10 Setia Bakti yang berjumlah 3 orang guru bidang Study yang terdiri dari 1 Guru PJOK, 1 guru PAI, dan 1 guru BTQ. Untuk pengumpulan data peneliti menggunakan bimbingan berkelanjutan yang berkelanjutan. Pengolahan data dilakukan dengan wawancara, pengamatan, dan observasi terhadap penyusunan perangkat pembelajaran oleh setiap guru bidang study. Berdasarkan penelitian ada peningkatan kemampuan guru dalam menyusun perangkat pembelajaran yang efektif sehingga proses pembelajaran lebih bermakna dan bermutu seperti yang diharapkan.
\end{abstract}

\section{Kata kunci : Bimbingan, Berkelanjutan, Kemampuan Guru, Perangkat Pembelajaran}

\section{PENDAHULUAN}

Perencanaan pembelajaran merupakan langkah yang sangat penting sebelum pelaksanaan pembelajaran. Perencanaan yang matang diperlukan supaya pelaksanaan pembelajaran berjalan secara efektif. Perencanaan pembelajaran dituangkan ke dalam perangkat pembelajaran atau beberapa istilah lain seperti desain pembelajaran, skenario pembelajaran dan lain sebagainya. Perangkat Pembelajaran memuat tingkat pencapaian perkembangan, indikator yang akan dicapai, materi yang akan dipelajari, metode pembelajaran, langkah pembelajaran, media pembelajaran, dan sumber belajar serta penilaian.

Peraturan Pemerintah Nomor 19 Tahun 2005 tentang 8 Standar Nasional Pendidikan menyatakan standar proses merupakan salah satu SNP untuk satuan pendidikan dasar dan menengah yang mencakup: 1) Perencanaan proses pembelajaran, 2) Pelaksanaan proses pembelajaran, 3) Penilaian hasil pembelajaran, 4) dan pengawasan proses pembelajaran

Perangkat pembelajaran dikembangkan oleh guru pada satuan pendidikan . Guru pada satuan pendidikan berkewajiban menyusun silabus, Perangkat Pembelajaran secara lengkap dan sistematis agar pembelajaran berlangsung secara interaktif, inspiratif, menyenangkan, menantang, memotivasi peserta didik untuk berpartisipasi aktif, serta memberikan ruang yang cukup bagi prakarsa, kreativitas, dan 
kemandirian sesuai dengan bakat, minat dan perkembangan fisik serta psikologis peserta didik.

Hal ini menyebabkan banyak guru yang belum tahu dan memahami penyusunan/pembuatan perangkat pembelajaran secara baik/lengkap. Beberapa guru mengadopsi perangkat pembelajaran orang lain. Hal ini peneliti ketahui pada saat mengadakan supervisi akademik (supervisi kunjungan kelas) ke sekolah binaan. Permasalahan tersebut berpengaruh besar terhadap pelaksanaan proses pembelajaran.

Berdasarkan uraian latar belakang di atas maka penulis tertarik untuk mengadakan penelitian yang akan dituangkan dalam sebuah bentuk tulisan laporan penelitian tindakan sekolah dengan judul "Penerapan Kegiatan Bimbingan Berkelanjutan Dalam Meningkatkan Kemampuan Guru Mata Pelajaran Dalam Menyusun Perangkat Pembelajaran Di SD Negeri 10 Setia Bakti Kecamatan Setia Bakti Kabupaten Aceh Jaya Tahun Pelajaran 2019/2020".

\section{Tujuan Penelitian}

Tujuan dari penelitian ini adalah untuk mengetahui Implementasi bimbingan berkelanjutan dalam meningkatkan kemampuan guru dalam menyusun Perangkat Pembelajaran di SD Negeri 10 Setia Bakti Kecamatan Setia Bakti Kabupaten Aceh Jaya.

\section{KAJIAN PUSTAKA \\ Pengertian Guru}

Rabindranath Tagore (dalam Suparlan 2005:11) menggunakan istilah Shanti Niketan atau rumah damai untuk tempat para guru mengamalkan tugas mulianya membangun spiritualitas anak-anak bangsa di India ( spiritual intelligence). Pengertian guru kemudian menjadi semakin luas, tidak hanya terbatas dalam kegiatan keilmuan yang bersifat kecerdasan spiritual (spiritual intelligence) dan kecerdasan intelektual (intellectual intelligence), tetapi juga menyangkut kecerdasan kinestetik jasmaniah (bodily kinesthetic), seperti guru tari, guru olah raga, guru senam dan guru musik. Dengan demikian, guru dapat diartikan sebagai orang yang tugasnya terkait dengan upaya mencerdaskan kehidupan bangsa dalam semua aspeknya, baik spiritual dan emosional, intelektual, fisikal, maupun aspek lainnya.

Poerwadarminta (dalam Suparlan 2005:13) menyatakan, "guru adalah orang yang kerjanya mengajar." Dengan definisi ini, guru disamakan dengan pengajar. Pengertian guru ini hanya menyebutkan satu sisi yaitu sebagai pengajar, tidak termasuk pengertian guru sebagai pendidik dan pelatih. Selanjutnya Zakiyah Daradjat (dalam Suparlan 2005:13) menyatakan," guru adalah pendidik profesional karena guru telah menerima dan memikul beban dari orang tua untuk ikut mendidik anak-anak.

UU Guru dan Dosen Republik Indonesia No.14 Tahun 2005 "Guru adalah pendidik profesional dengan tugas utama mendidik, mengajar, membimbing, mengarahkan, melatih, menilai, dan mengevaluasi peserta didik pada pendidikan anak usia dini jalur pendidikan formal, pendidikan dasar, dan pendidikan menengah".

Selanjutnya UU No.20 Tahun 2003 pasal 39 ayat 2 tentang sistem pendidikan nasional menyatakan, "pendidik merupakan tenaga profesional yang bertugas merencanakan dan melaksanakan proses pembelajaran, menilai hasil pembelajaran, melakukan pembimbingan dan pelatihan, serta melakukan penelitian dan pengabdian kepada masyarakat, terutama bagi pendidik pada perguruan tinggi." PP No.19 Tahun 2005 tentang Standar Nasional Pendidikan menyatakan, "pendidik (guru) harus memiliki kualifikasi akademik dan kompetensi sebagai agen pembelajaran, sehat 
jasmani dan rohani, serta memiliki kemampuan untuk mewujudkan tujuan pendidikan nasional."

Berdasarkan definisi di atas, dapat disimpulkan bahwa guru adalah tenaga pendidik yang profesional dengan tugas utama mendidik, mengajar, membimbing, mengarahkan, melatih, menilai dan mengevaluasi peserta didik, dan bertugas merencanakan dan melaksanakan proses pembelajaran.

\section{Standar Kompetensi Guru}

Definisi di atas dapat disimpulkan standar Kompetensi guru adalah suatu pernyataan tentang kriteria yang dipersyaratkan, ditetapkan dalam bentuk penguasaan perangkat kemampuan yang meliputi pengetahuan, sikap, nilai dan keterampilan bagi seorang tenaga kependidikan sehingga layak disebut kompeten. Standar kompetensi guru dipilah ke dalam tiga komponen yang kait- mengait, yakni:

1) Pengelolaan pembelajaran,

2) Pengembangan profesi, dan

3) Penguasaan akademik.

Komponen pertama terdiri atas empat kompetensi, komponen kedua memiliki satu kompetensi, dan komponen ketiga memiliki dua kompetensi.

\section{Perangkat Pembelajaran}

Permendiknas No. 41 Tahun 2007 menyatakan dalam menyusun rencana pelaksanaan pembelajaran (RPP) harus memperhatikan prinsip-prinsip sebagai berikut: a) memperhatikan perbedaan individu peserta didik, b) mendorong partisipasi aktif peserta didik, c) mengembangkan budaya membaca dan menulis, d) memberikan umpan balik dan tindak lanjut, e) keterkaitan dan keterpaduan.

\section{Hal-Hal yang Perlu Diperhatikan dalam Menyusun Perangkat Pembelajaran}

Dalam penyusunan Perangkat Pembelajaran perlu memperhatikan hal sebagai berikut: (a) Perangkat Pembelajaran disusun untuk setiap KD yang dapat dilaksanakan dalam satu kali pertemuan atau lebih, b) tujuan pembelajaran menggambarkan proses dan hasil belajar yang harus di capai oleh peserta didik sesuai dengan kompetenrsi dasar, c) tujuan pembelajaran dapat mencakupi sejumlah indikator, atau satu tujuan pembelajaran untuk beberapa indikator, yang penting tujuan pembelajaran harus mengacu pada pencapaian indikator, d) Kegiatan pembelajaran (langkah-langkah pembelajaran) dibuat setiap pertemuan, bila dalam satu Perangkat Pembelajaran terdapat 3 kali pertemuan, maka dalam Perangkat Pembelajaran tersebut terdapat 3 langkah pembelajaran, e). Bila terdapat lebih dari satu pertemuan untuk indikator yang sama, tidak perlu dibuatkan langkah kegiatan yang lengkap untuk setiap pertemuannya.

\section{Bimbingan Berkelanjutan}

Frank Parson. 1951 (dalam RM Fatihah http://eko13.wordpress.com) menyatakan, "bimbingan sebagai bantuan yang diberikan kepada individu untuk dapat memilih, mempersiapkan diri dan memangku suatu jabatan dan mendapat kemajuan dalam jabatan yang dipilihnya." Chiskon 1959 (dalam RM Fatihah http://eko13.wordpress.com) menyatakan, "bimbingan membantu individu untuk lebih mengenal berbagai informasi tentang dirinya sendiri."

Bimbingan adalah pemberian bantuan kepada individu secara berkelanjutan dan sistematis yang dilakukan oleh seorang ahli yang telah mendapat latihan khusus untuk itu,dimaksudkan agar individu dapat memahami dirinya, lingkungannya, serta dapat 
mengarahkan diri dan menyesuaikan diri dengan lingkungan untuk dapat mengembangkan potensi dirinya secara optimal untuk kesejahteraan dirinya dan kesejahteraan masyarakat.

Berdasarkan pengertian bimbingan dan berkelanjutan dapat ditarik suatu kesimpulan bahwa bimbingan berkelanjutan adalah pemberian bantuan yang diberikan seorang ahli kepada seseorang atau individu secara berkelanjutan berlangsung secara terus menerus untuk dapat mengembangkan potensi dirinya secara optimal dan mendapat kemajuan dalam bekerja.

METODOLOGI PENELITIAN.

Tempat dan Waktu Penelitian

Penelitian Tindakan Sekolah ini di adakan di SD Negeri 10 Setia Bakti Kecamatan Setia Bakti Kabupaten Aceh Jaya. PTS ini dilaksanakan pada semester genap tahun pelajaran 2019-2020 mulai 25 September s.d 10 Oktober 2019.

\section{Subjek Penelitian}

Subyek dalam PTS ini adalah guru mata pelajaran di SD Negeri 10 Setia Bakti Kecamatan Setia Bakti Kabupaten Aceh Jaya. Berikut ini adalah nama nama subjek penelitian :

Tabel Subjek Penelitian

\begin{tabular}{|c|l|c|}
\hline No. & \multicolumn{1}{|c|}{ Nama Guru } & Bid.Study yg diampu \\
\hline 1 & Neuleili, S.Pd.I & PAI \\
\hline 2 & Desianti, A.Ma & BTQ \\
\hline
\end{tabular}

\section{Prosedur Penelitian}

Penelitian ini berbentuk Penelitian Tindakan Sekolah (School Action Research), yaitu sebuah penelitian yang merupakan kerjasama antara peneliti dan guru, dalam meningkatkan kemampua guru agar menjadi lebih baik dalam menyusun rencana pelaksanaan pembelajaran

Prosedur penelitian adalah suatu rangkaian tahap-tahap penelitian dari awal sampai akhir. Penelitian ini merupakan proses pengkajian sistem berdaur sebagaimana kerangka berpikir yang dikembangkan oleh Suharsimi Arikunto dkk. Prosedur ini mencakup tahap-tahap :

(1) Perencanaan,

(2) Pelaksanaan,

(3) Pengamatan, dan

4) Refleksi.

\section{Alat Pengumpulan Data} diskusi.

Teknik pengumpulan data dalam penelitian ini adalah wawancara, observasi, dan

\section{Tekhnik Analisa Data}

Langkah-langkah yang perlu dilakukan dalam analisis data seperti ini adalah sebagai berikut.
a) Memilih data (reduksi data)
b) Mendeskripsikan data hasil temuan (memaparkan data)
c) Menarik kesimpulan hasil deskripsi 


\section{HASIL PENELITIAN DAN PEMBAHASAN \\ Hasil Observasi pada Siklus I}

Proses Pembelajaran yang dilakukan pada guru bidang study PAI mulai dari kelas I s.d III di SD Negeri 10 Setia Bakti Kecamatan Setia Bakti Kabupaten Aceh Jaya tentunya dilengkapi dengan semua perangkat pembelajaran, sebelum dilakukan penelitian semua dianjurkan membuat semua perangakat pembelajarannya.

Berdasarkan pengamatan terhadap observasi guru bidang study PAI (an. (Nurleili, S.Pd.I), dan BTQ (Desianti, A.Ma) pada kelas I s.d III, setelah dilaksanakan penelitian menunjukkan bahwa masih rendahnya kemampuan guru dalam membuat perangkat pembelajaran. Hal ini dapat dibuktikan pada tabel di bawah ini :

\section{Tabel Nilai Observasi Guru Dalam Membuat Perangkat Pembelajaran} Tahap Siklus I

\begin{tabular}{|c|c|c|c|c|c|c|}
\hline No & Mapel & I & II & III & Rata-rata & Katagori \\
\hline 1 & PAI & 70 & 65 & 60 & 67 & Kurang \\
\hline 2 & BTQ & 60 & 60 & 65 & 64 & Kurang \\
\hline \multicolumn{2}{|c|}{ Jumlah } & $\mathbf{6 5}$ & $\mathbf{6 2}$ & $\mathbf{6 3}$ & $\mathbf{6 5}$ & Kurang \\
\hline
\end{tabular}

Tabel diatas menunjukkan bahwa penilai guru dalam membuat perangkat masih dalam katagori kurang, dimana nilai rata-rata dari guru PAI 67, dan guru BTQ hanya 64. Hal ini menunjukkan bahwa kemampuan guru dalam membuat perangkat perlu ada perbaikan dan bimbingan pada siklus selanjutnya.

\section{Deskripsi Hasil Penelitian} Siklus I

Siklus I dilaksanakan pada tanggal 25 September 2019 s.d 30 September 2019 dengan jumlah guru mapel yaitu PAI, dan BTQ. Siklus I dilaksanakan dalam empat tahap, tahapan-tahapan tersebut antara lain :

a. Perencanaan

Langkah pertama yang dilakukan sebelum melaksanakan penelitian adalah mempersiapkan format wawancara kesediaan Rencana Pelaksanaan Pembelajaran (RPP) guru.

b. Pelaksanaan

Peneliti memberikan bimbingan dalam merancang dan meyusun perangkat pembelaran yang baik.

c. Pengamatan/Obeservasi

Peneliti melakukan pengamatan terhadap perangkat pembelajaran yang telah dibuat untuk memotret seberapa jauh kemampuan guru dalam menyusun perangkat pembelajaran dengan lengkap, hasil atau dampak dari tindakan yang telah dilaksanakan oleh guru dalam mencapai sasaran. Hasil rekapitulasi data tersebut dapat dilihat sebagai berikut :

Tabel Rekapitulasi Lembar Pengamatan Penyusunan Perangkat Pembelajaran Siklus I

\begin{tabular}{|c|l|c|c|c|c|}
\hline No & \multicolumn{1}{|c|}{ Aspek yang dinilai } & PAI & BTQ & $\begin{array}{c}\text { Rata- } \\
\text { rata }\end{array}$ & $\begin{array}{c}\text { Perentase } \\
(\%)\end{array}$ \\
\hline 1 & $\begin{array}{l}\text { Kemampuan mengembangkan } \\
\text { indikator }\end{array}$ & 3 & 3 & 3 & $60 \%$ \\
\hline 2 & $\begin{array}{l}\text { Kemampuan merumuskan tujuan } \\
\text { pembelajaran }\end{array}$ & 4 & 4 & 4 & $65 \%$ \\
\hline 3 & Kemampuan dalam menentukan & 4 & 3 & 3 & $60 \%$ \\
\hline
\end{tabular}




\begin{tabular}{|c|l|c|c|c|c|}
\hline & materi/bahan ajar & & & & \\
\hline 4 & $\begin{array}{l}\text { Kemampuan dalam menentukan } \\
\text { sumber belajar }\end{array}$ & 3 & 3 & 3 & $60 \%$ \\
\hline 5 & $\begin{array}{l}\text { Kemampuan menetukan metode } \\
\text { pembelajaran }\end{array}$ & 3 & 4 & 3 & $60 \%$ \\
\hline 6 & $\begin{array}{l}\text { Kemampuan menetunkan media } \\
\text { pembelajaran }\end{array}$ & 2 & 3 & 3 & $60 \%$ \\
\hline 7 & Kemampuan menetukan penilaian & 3 & 3 & 3 & $60 \%$ \\
\hline
\end{tabular}

Rekapitulasi data pengamatan guru di atas dapat diketahui bahwa pengamatan terhadap persentase kemampuan guru dalam menyusun perangkat pembelajaran hanya $60 \%$.

\section{d. Refleksi Siklus I}

Berdasarkan hasil pengamatan Peneliti mengkaji, melihat, dan mempertimbangkan hasil atau dampak dari tindakan yang telah dilakukan. Berdasarkan hasil dari refleksi ini, peneliti bersama guru melaksanakan revisi atau perbaikan terhadap perangkat pembelajaran yang telah disusun agar sesuai dengan rencana awal yang mungkin saja masih bisa sesuai dengan yang peneliti inginkan.

\section{Siklus II}

Hasil penelitian pada siklus I belum memuaskan dan belum mencapai indikator keberhasilan yang ditentukan peneliti, maka dilanjutkan ke siklus II yang dilaksanakan pada tanggal 27 s.d 30 September 2019, dengan jumlah guru yang sama yaitu guru PAI, dan BTQ.

Tahapan-tahapan pada siklus II sama dengan tahapan yang dilakukan pada siklus I, Cuma pada siklus II ini adalah : menyelidiki kembali hasil perbaikan guru dalam menyusun semua perangkat pembelajaran.

Hasil rekapitulasi data tersebut dapat dilihat sebagai berikut :

Tabel Rekapitulasi Lembar Pengamatan Penyusunan

Perangkat Pembelajaran Siklus II

\begin{tabular}{|c|l|c|c|c|c|}
\hline No & \multicolumn{1}{|c|}{ Aspek yang dinilai } & PAI & BTQ & $\begin{array}{c}\text { Rata- } \\
\text { rata }\end{array}$ & $\begin{array}{c}\text { Perentase } \\
(\%)\end{array}$ \\
\hline 1 & $\begin{array}{l}\text { Kemampuan mengembangkan } \\
\text { indikator }\end{array}$ & 4 & 4 & 4 & $100 \%$ \\
\hline 2 & $\begin{array}{l}\text { Kemampuan merumuskan tujuan } \\
\text { pembelajaran }\end{array}$ & 4 & 4 & 4 & $100 \%$ \\
\hline 3 & $\begin{array}{l}\text { Kemampuan dalam menentukan } \\
\text { materi/bahan ajar }\end{array}$ & 4 & 4 & 4 & $100 \%$ \\
\hline 4 & $\begin{array}{l}\text { Kemampuan dalam menentukan } \\
\text { sumber belajar }\end{array}$ & 4 & 4 & 4 & $100 \%$ \\
\hline 5 & $\begin{array}{l}\text { Kemampuan menetukan metode } \\
\text { pembelajaran }\end{array}$ & 4 & 4 & 4 & $100 \%$ \\
\hline 6 & $\begin{array}{l}\text { Kemampuan menetunkan media } \\
\text { pembelajaran }\end{array}$ & 4 & 4 & 4 & $100 \%$ \\
\hline 7 & \begin{tabular}{l} 
Kemampuan menetukan penilaian \\
\hline
\end{tabular} & 4 & 4 & 4 & $100 \%$ \\
\hline
\end{tabular}

Rekapitulasi data pengamatan guru di atas dapat diketahui bahwa pengamatan terhadap kemampuan guru dalam menyusun perangkat pada siklus II diperoleh skor persentase $100 \%$ pada kategori baik. 


\section{Pembahasan}

Dengan kerjasama antara peneliti dengan dewan guru dalam melakukan bimbingan terhadap menyusun perangkat pembelajaran akan menghasilkan hasil yang baik. Hasil kemampuan guru dalam menyusun perangkat pembelajaran meningkat dari setiap siklusnya, hal ini dapat dibuktikan dengan rekapitulasi data perbandingan antara siklus I dan siklus II sebagai berikut :

Tabel Rekapitulasi Lembar perbandingan Pengamatan Penyusunan Perangkat Pembelajaran antara siklus I dan Siklus II

\begin{tabular}{|c|c|c|c|c|c|c|c|}
\hline Nama & \multicolumn{7}{|c|}{ Aspek yang dinilai } \\
\hline $\begin{array}{l}\text { Nurleili, } \\
\text { S.Pd.I }\end{array}$ & $\begin{array}{c}\text { Kemampu } \\
\text { an } \\
\text { mengemba } \\
\text { ngkan } \\
\text { indikator }\end{array}$ & $\begin{array}{c}\text { Kemam } \\
\text { puan } \\
\text { merum } \\
\text { uskan } \\
\text { tujuan } \\
\text { pembel } \\
\text { ajaran }\end{array}$ & $\begin{array}{c}\text { Kemamp } \\
\text { uan dalam } \\
\text { menentuk } \\
\text { an } \\
\text { materi/ba } \\
\text { han ajar }\end{array}$ & $\begin{array}{l}\text { Kemam } \\
\text { puan } \\
\text { dalam } \\
\text { menent } \\
\text { ukan } \\
\text { sumber } \\
\text { belajar } \\
\end{array}$ & $\begin{array}{c}\text { Kema } \\
\text { mpuan } \\
\text { menetu } \\
\text { kan } \\
\text { metode } \\
\text { pembel } \\
\text { ajaran } \\
\end{array}$ & $\begin{array}{c}\text { Kemam } \\
\text { puan } \\
\text { menetu } \\
\text { nkan } \\
\text { media } \\
\text { pembel } \\
\text { ajaran }\end{array}$ & $\begin{array}{c}\text { Kemampu } \\
\text { an } \\
\text { menetukan } \\
\text { penilaian }\end{array}$ \\
\hline Siklus I & 3 & 4 & 4 & 3 & 3 & 2 & 3 \\
\hline Siklus II & 4 & 4 & 4 & 4 & 4 & 4 & 4 \\
\hline $\begin{array}{c}\text { Nama Guru } \\
\text { BTQ }\end{array}$ & \multicolumn{7}{|c|}{ Aspek yang dinilai } \\
\hline $\begin{array}{l}\text { Desianti, } \\
\text { A.Ma }\end{array}$ & $\begin{array}{l}\text { Kemamp } \\
\text { uan } \\
\text { mengemb } \\
\text { angkan } \\
\text { indikator }\end{array}$ & $\begin{array}{l}\text { Kemam } \\
\text { puan } \\
\text { merum } \\
\text { uskan } \\
\text { tujuan } \\
\text { pembel } \\
\text { ajaran }\end{array}$ & $\begin{array}{c}\text { Kemamp } \\
\text { uan dalam } \\
\text { menentuk } \\
\text { an } \\
\text { materi/ba } \\
\text { han ajar }\end{array}$ & $\begin{array}{l}\text { Kemam } \\
\text { puan } \\
\text { dalam } \\
\text { menent } \\
\text { ukan } \\
\text { sumber } \\
\text { belajar }\end{array}$ & $\begin{array}{c}\text { Kema } \\
\text { mpuan } \\
\text { menetu } \\
\text { kan } \\
\text { metode } \\
\text { pembel } \\
\text { ajaran }\end{array}$ & $\begin{array}{c}\text { Kemam } \\
\text { puan } \\
\text { menetu } \\
\text { nkan } \\
\text { media } \\
\text { pembel } \\
\text { ajaran }\end{array}$ & $\begin{array}{c}\text { Kemampu } \\
\text { an } \\
\text { menetukan } \\
\text { penilaian }\end{array}$ \\
\hline Siklus I & 3 & 4 & 3 & 3 & 3 & 3 & 3 \\
\hline Siklus II & 4 & 4 & 4 & 4 & 4 & 4 & 4 \\
\hline
\end{tabular}

Pada siklus I hasil kemampuan guru masih dibawah rata-rata hanya sebesar $60 \%$ sementara pada sikus II dapat diketahui bahwa terjadi peningkatan jumlah persentase yang mencapai $100 \%$.

Target ketuntasan tersebut dapat digambarkan dalam diagram di bawah ini :

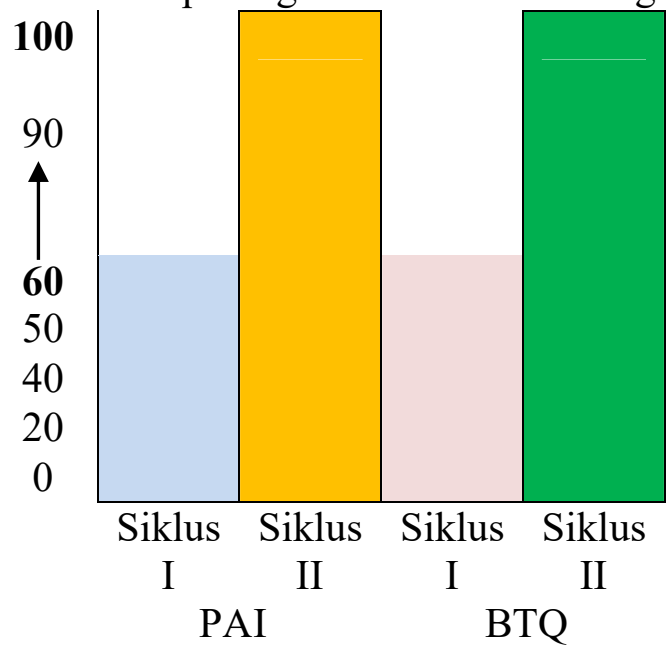

Gambar Persentase siklus I dan siklus II 
Persentase ketuntasan yang diperoleh pada setiap siklusnya juga mengalami peningkatan. Kriteria ketuntasan klasikal yang digunakan peneliti adalah apabila persentase ketuntasan klasikal mencapai maka penelitian dapat dikatakan berhasil.

Kriteria ketuntasan dinyatakan dengan nilai 4 (100\%), sementara pada siklus I hanya mendapat reratanya $3(60 \%)$ dan pada siklus II persentase meningkat menjadi $(100 \%)$ karena sudah mendapat nilai 4.

\section{Kesimpulan}

Berdasarkan hasil penelitian yang dilakukan di SD Negeri 10 Setia Bakti Kecamatan Setia Bakti Kabupaten Aceh Jaya, dapat disimpulkan yaitu meningkatkan kemampuan guru dalam menyusun perangkat pembelajaran dengan diadakan pengamatan terhadap perangkat pembelajaran guru. Kemampuan guru dalam menyusun Rencana Pelaksanaan Pembelajaran (RPP) dapat dicermati melalui kemampuannya dalam merancang setiap komponen pembelajaran secara terpadu. Komponen pembelajaran yang dimaksud meliputi: pengembangan indikator; penentuan tujuan pembelajaran; penentuan materi/bahan ajar; penentuan sumber belajar; penentuan metode pembelajaran; penentuan media pembelajaran; dan penilaian, hal ini perlu di asah terus-menurus sehingga proses pembelajaran yang dilakukan guru agar menciptakan pembaharuan menuju kearah pendidikan yang maju dan bermutu.

\section{DAFTAR PUSTAKA}

Arikunto, Suharsimi. 2002. Prosedur Penelitian, Suatu Pendekatan Praktek. Jakarta: PT Rineka Cipta

Depdiknas. 2003. UU RI No. 20 Tahun 2003 tentang Sistem Pendidikan Nasional. Jakarta: Depdiknas. 2004. Standar Kompetensi Guru Sekolah Dasar. Jakarta: Depdiknas. 2005. UU RI No. 14 Tahun 2005 tentang Guru dan Dosen. Jakarta: Depdiknas. 2005. Standar Nasional Pendidikan. Jakarta: Depdiknas. 2007. Permendiknas RI No. 41 Tahun 2007a tentang Standar Proses. Jakarta: Depdiknas.

Fatihah, RM . 2008. Pengertian konseling (Http://eko13.wordpress.com, diakses 19 Maret 2009).

Suparlan. 2005. Menjadi Guru Efektif. Yogyakarta: Hikayat Publishing. 2006. Guru Sebagai Profesi. Yogyakarta: Hikayat Publishing. 